\title{
The species of membracids described by C. Berg and M. Spinola classified in Sundarion Kirkaldy (Hemiptera, Cicadomorpha, Membracidae) ${ }^{1}$
}

\author{
Albino M. Sakakibara ${ }^{2,4} \&$ Antonio J. Creão-Duarte ${ }^{3}$
}

${ }^{1}$ Contribution $n^{\circ} 1559$ of the Departamento de Zoologia, Universidade Federal do Paraná.

${ }^{2}$ Departamento de Zoologia, Universidade Federal do Paraná. Caixa Postal, 19020, 81531-980 Curitiba-PR, Brazil. sakaki@bsi.com.br ${ }^{3}$ Departamento de Sistemática e Ecologia, Universidade Federal da Paraíba. 58059-900 João Pessoa-PB, Brazil. creao@dse.ufpb.br ${ }^{4} \mathrm{CNPq}$ fellowship.

\begin{abstract}
The species of membracids described by C. Berg and M. Spinola classified in Sundarion Kirkaldy (Hemiptera, Cicadomorpha, Membracidae). Pyranthe acaciae Berg, 1883 and Hemiptycha chilensis Spinola, 1852 are reinstated in Sundarion Kirkaldy, 1904 (formerly in synonymy of Callicentrus bonasia (Fabricius, 1775) (Centrotinae, Nessorhinini)). Pyranthe frustratoria Berg, 1883 (also formerly considered as synonym of Callicentrus bonasia) becomes a new synonym of Sundarion flavomarginatum (Fairmaire, 1846).
\end{abstract}

KEYWORDS. Auchenorrhyncha; Darninae; Homoptera; nomenclatural acts; taxonomy.

RESUMO. As espécies de membracídeos descritas por C. Berg e M. Spinola classificadas em Sundarion Kirkaldy (Hemiptera, Cicadomorpha, Membracidae). Pyranthe acaciae Berg, 1883 e Hemiptycha chilensis Spinola, 1852 são revalidadas em Sundarion Kirkaldy, 1904 (anteriormente colocadas em sinonímia de Callicentrus bonasia (Fabricius, 1775) (Centrotinae, Nessorhinini)). Pyranthe frustratoria Berg, 1883 (também considerada anteriormente como sinônimo de Callicentrus bonasia) torna-se um novo sinônimo de Sundarion flavomarginatum (Fairmaire, 1846).

PALAVRAS-CHAVE. Atos nomenclaturais; Auchenorrhyncha; Darninae; Homoptera; taxonomia.

Berg (1883) described Pyranthe acaciae and P. frustratoria, respectively from Uruguay and Argentina. Spinola (1852) described Hemiptycha chilensis, from Chile. Kirkaldy (1904) created Sundarion to substitute the preoccupied name Pyranthe Stål, 1869.

Funkhouser (1927) considered the three species as valid, in Sundarion. Metcalf \& Wade (1965), on the other hand, put $P$. acaciae under the synonym of Sundarion apicalis (Germar, 1835), and transferred $P$. frustratoria and $H$. chilensis into the Hemikypthini genus Callicentrus Stål, 1869, as synonyms of $C$. bonasia (Fabricius, 1775).

McKamey (1998) practically repeated the classification given in Metcalf \& Wade (1965), but considering the genus in Nessorhininae-Nessorhinini as Deitz (1975). He also commented that all junior synonyms of Callicentrus bonasia (Fabricius) should be examined, because they were, probably, misassigned.

In the present paper, Sundarion acaciae (Berg) and S. chilense (Spinola) are reinstated; Pyranthe frustratoria Berg is considered junior synonym of Sundarion flavomarginatum (Fairmaire, 1846).

Abbreviations used: DZUP-Coleção de Entomologia Pe. J. S. Moure, Departamento de Zoologia, UFPR, Curitiba-PR, Brazil; MZSP- Museu de Zoologia-USP, São Paulo-SP, Brazil; MLPAMuseo de La Plata, Argentina.

Sundarion acaciae (Berg, 1883) reval.

(Fig. 1)

Pyranthe acaciae Berg, 1883: 290; McKamey, 1998: 154 (cat.) (= Sundarion apicalis (Germar, 1835)) (error).

Sundarion acaciae; Funkhouser, 1927: 162.
Comments. Sundarion acaciae is somewhat similar to $S$. flavum (Fairmaire, 1846), but having short and blackish suprahumeral processes; the lateral margins of posterior process with a faint yellow band and, frequently, with a dark spot near middle.

The type of Smilia apicalis Germar, 1835 was not seen. Based simply on the original description is difficult to say if it is actually synonym of $S$. acaciae. Therefore, Sundarion apicalis (Germar, 1835) is maintained as a good species.

Material examined. BRAZIL. Mato Grosso do Sul: Rio Brilhante, 5 males (DZUP). Goiás: Cabeceiras (Lagoa Formosa), 1 male (MZSP). Paraná: Guarapuava, 1 female (DZUP).

Photograph of a syntype specimen of Pyranthe acaciae Berg, 1883 (MLPA).

\section{Sundarion chilense (Spinola, 1852) reval.}

(Fig. 2)

Hemiptycha chilensis Spinola, 1852: 270; McKamey, 1998: 216 (cat.) (= Callicentrus bonasia (Fabricius, 1775)) (error).

Sundarion chilensis [sic]; Funkhouser, 1927: 163.

Comments. Sundarion chilense also presents lateral yellow stripe, very similar to that of $S$. flavomarginatum. The suprahumeral processes, on the other hand, are very short, reduced to conical projections. It is known only from Chile.

Material examined. CHILE. Santiago, 2 females (MZSP). 

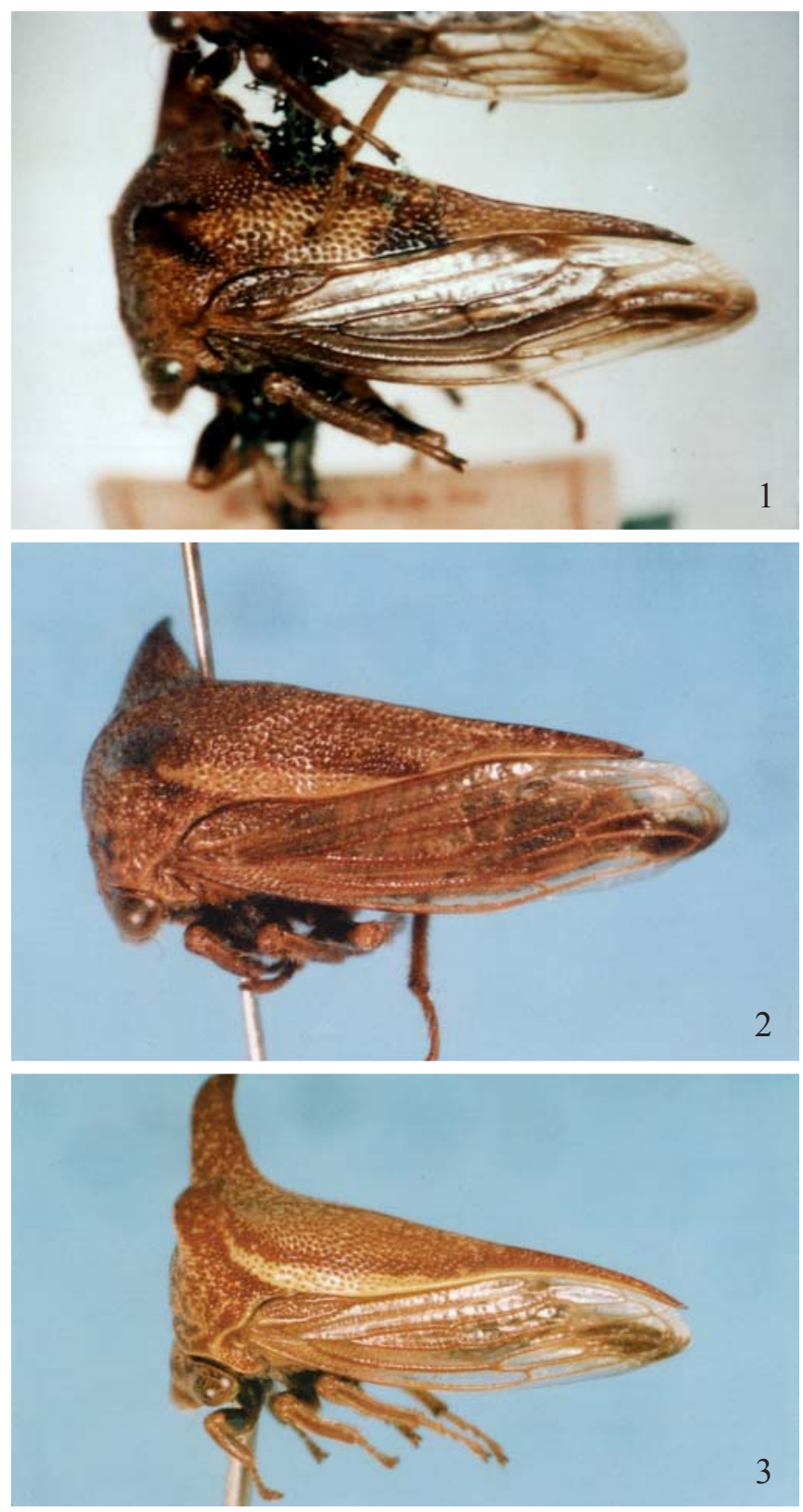

Figs. 1-3. 1, Pyranthe acaciae Berg, 1883 (one of the syntypes); 2, Sundarion chilense (Spinola, 1852); 3, Sundarion flavomarginatum (Fairmaire, 1846).
Sundarion flavomarginatum (Fairmaire, 1846)

(Fig. 3)

Hemiptycha flavomarginata Fairmaire, 1846: 315.

Pyranthe frustratoria Berg, 1883: 296; McKamey, 1998: 216 (cat.) (= Callicentrus bonasia (Fabricius, 1775)) (error). Syn. nov. Sundarion frustratoria [sic]; Funkhouser, 1927: 163

Sundarion flavomarginata [sic]; Funkhouser, 1927: 163.

Sundarion flavomarginatum; McKamey, 1998: 154 (cat.).

Comments. As the name suggests, the species presents a yellow stripe at each side of the posterior process extended from the base of supra-humeral processes to beyond middle. This character, quite identical with that of Callicentrus bonasia (Fabricius, 1775), together with the body length, and the suprahumeral horns well developed and divaricated, were probably the reason why these two species have been considered synonyms. The posterior process is slender and long, almost reaching apex of tegmina.

Material examined. BRAZIL. Paraná: Curitiba, 2 males. Santa Catarina: Nova Teutônia, 3 females, 2 males (DZUP).

Photograph of a syntype specimen of Pyranthe frustratoria Berg, 1883 (MLPA).

Acknowledgements. We are grateful to Olaf H. H. Mielke (DZUP) for the photographs taken from the Berg's types at Museo de La Plata, Argentina.

\section{REFERENCES}

Berg, C. 1883. Addenda et emendanda ad Hemiptera Argentina. Anales de la Sociedad Científica Argentina 16: 285-294.

Fairmaire, L. 1846. Revue de la tribu des Membracides. Annales de la Société Entomologique de France 4: 235-320.

Funkhouser, W. D. 1927. Membracidae. General Catalogue of the Hemiptera. Fasc. 1. Smith College, Northampton, Massachusetts. $581 \mathrm{p}$.

Kirkaldy, G. 1904. Bibliographical and nomenclatorial notes on the Hemiptera. No.3. The Entomologist 37: 279-283.

McKamey, S. H. 1998. Taxonomic catalogue of the Membracoidea (exclusive of leafhoppers): second supplement to fascicle I Membracidae of the General Catalogue of the Hemiptera. Memoirs of the American Entomological Institute 60: 1-377.

Metcalf, Z. P. \& V. Wade. 1965. General Catalogue of the Homoptera. A supplement to fascicle I - Membracidae of the General Catalogue of the Hemiptera. Membracoidea. Sections I-II. North Carolina State University, Raleigh. 1552 p. Spinola, M. 1852. Tribu IV. Hipocephalocera. In: C. Gay. Historia Fisica y Politica de Chile. Zoologia. 7: 238-305. 